\title{
ARCHAEQLOGIA :
}

OR,

\section{I S C E L A N E O U S T R A C T S \\ RELATING TO \\ ANTIQUITY.}




\section{ARCHAEOLOGIA :}

OR,

\section{MISCELLANEOUS TRACTS}

RULATING TO

\section{A NTIQUITY,}

PUBLISHED BY THE

\section{SOCIETY OF ANTIQUARIES OF LONDON.}

\section{VOLUME XXXI.}

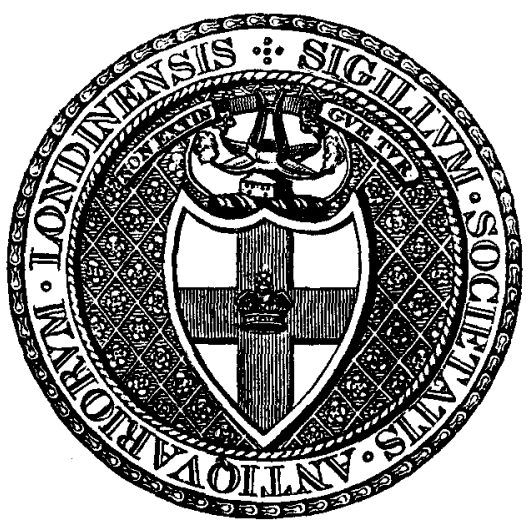

\section{LONDON :}

PRINTED BY J. B. NICHOLS AND SON, 25, PARLIAMENT STREET.

SOLD AT THE SOCIETY'S APARTMENTS IN SOMERSET PLACE, AND BY MESSRS. PAYNE AND FOSS, PALL MALL, AND W. PICKERING, PICCADILLY.

M.DCCC.XLVI. 


\section{TABLE OF CONTENTS.}

PAGE

I. Observations on the Institution of the Most Noble Order of the Garter. By Sir Nicholas Harris Nicolas, G.C.M.G., addressed to Hudson Gurney, Esq., F.R.S., Vice-President; illustrated by the Actounts of the Great Wardrobe of King Edward the Third, from the 29th of September 1344 to the 1 st of August 1345 ; and again from the 21 st of December

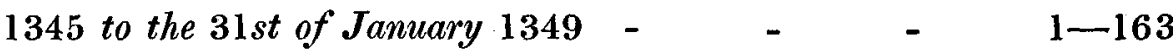

II. Remarks on some of the Stall-Plates of the Knights of the Garter. By Thomas William King, Esq., F.S.A., Rouge Dragon, in a Letter to Albert Way, Esq., Director $\quad 164-181$

III. Notes upon a Preceptory of the Templars at Garway, in the County of Hereford, with Plans, Copies of Inscriptions, and Illustrations of a Building of the Hospitallers at that place. $B y$ the Rev. John WeBв, F.S.A., Rector of Tretire in Herefordshire, in a Letter to Sir Henry Ellis, K.H., F.R.S., Secretary

IV. On the Municipal Archives of the City of Canterbury. By

Thomas Wright, Esq., M.A., F.S.A., Hon.M.R.S.L., Corresponding Member of the Institute of France, \&c. ; as communicated to the Society of Antiquaries by the Central Committee of the British Archaological Association 198-211

V. Letter of Sir Thomas Stanhope, of Shelford, co. Notts., to Lord Treasurer Burghley, respecting the Funeral of his Mother, Anne Lady Stanhope. Communicated by RICHARD Almack, Esq. F.S.A., in a Letter to Albert Way, Esq. M.A., Director $212-215$ 
VI. Observations upon the Succession to the Barony of William of Arques, in the County of Kent, during the period between the Conquest of England and the Reign of King John. By Thomas Stapleton, Esq. F.S.A.: as communicated to the Society of Antiquaries by the Central Committe of the Archeological Association - $\quad$ - 216-237

VII. Observations on the Monumental Effigy of De Mauley, in the Minster at York. By Sir Samuel Rush MeYrick, K.H., LL.D., F.S.A.: in a Letter to Albert Way, Esq. M.A.,

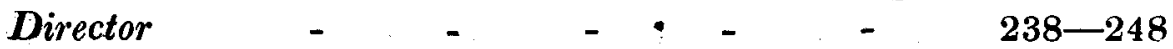

VIII. Account of the Discovery of the Episcopal Rings of John Stanbery and Richard Mayo, Bishops of Hereford, during the progress of recent works of restoration at Hereford Cathedral. By the Very Rev. John Merewether, F.S.A., Dean of

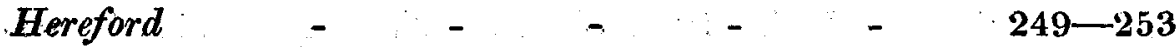

IX. Observations on a.Vase found at Sandy, in Bedfordshire. By Samuel Brrch, Esq., F.S.A., Assistant Keeper of the Antiquities in the British Museum, in a Letter addressed to Sir Henry Ellis, K.H., F.R.S., Secretary - ～- 254-256

X. Observations on the Figures of Anacreon and his Dog, as represented upon some Greek Fictile Vases in the British Museum. By Samuel Birch, Esq., F.S.A., Assistant Keeper of the Antiquities in that Institution

XI. Note on a Vase with Pelops Plexippus, in the British Museum. By Samuel Birch, Esq., F.S.A., Assistant Keeper of the Antiquities in the British Museum 265,266

XII. Observations on Incised Sepulchral Slabs, with Descriptions of two remarkable examples, representing Knights in the crosslegged attitude, which exist at Avenbury, in Herefordshire, and Bitton, in Gloucestershire. Communicated by AlBERT WAY, Esq., Director, in a Letter to Sir Henry Ellis, K.H., F.R.S., Secretary $267-274$ 
XIII. Account of a Bilingual Inscription taken from a Vase at St. Mark, at Venice, by T. J. PetTigrew, Esq., F.R.S., F.S.A. Communicated to the Society of Antiquaries by the Council of the British Archerological AssoCIATION - $\quad 275-278$

XIV. On some Roman Vestigia recently found at Kirkby Thore, in Westmoreland: in a Letter from Captain W. H. Sмхтн, R.N., K.S.F., D.C.L., President of the Royal Astronomical Society of London, \&c. to Sir Henry Ellis, K.H., F.R.S., \&c., Secretary - $\quad$ - $\quad$ - $\quad$ - $\quad 279-288$

XV. Some Observations on the White Horse of Berkshire; by

William J. Thoms, Esq., F.S.A.: in a Letter addressed to Thomas Amyot, Esq., Treasurer of the Society 289-298

XVI. On some early Remains discovered in Yorkshire, by J. M. N. Colss, Esq.: in a Letter to Edward Hailstone, Esq., F.S.A., of Bradford. Communicated to the Society of Antiquaries by the Committe of the Archaological

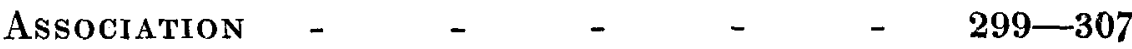

XVII. Notice of a leaden Coffin, of early fabric, discovered at Bow: as communicated in a Letter from CharLes Roach SMITH, Esq., F.S.A., to Nicholas Carlisle, Esq., K.H., F.S.A., Secretary $308-311$

XVIII. Letter from the Rev. L. Vernon Harcourt to Sir Henry Ellis, K.H., Secretary, describing several Vessels of glass and earthenware, and. Ornaments, discovered near Chilgrove, in Sussex - $\quad$ - $\quad$ - $\quad$ - $\quad$ - $312-317$

XIX. Letter from Thomas LotT, Esq., F.S.A., to Sir Henry Ellis, K.H., Secretary, describing some Remains of ancient Buildings on the west side of Bow Churchyard 318-322

XX. Observations on a portion of the Crypt of St. Stephen's Chapel, Westminster : communicated in a Letter from $\mathrm{T}$. Grisseld, Esq., to Sir Henry Ellis, K.H., F.R.S., Secretary - 
XXI. Account of the Ceremonial of the Marriage of the Princess PAGE Margaret, sister of King Edward the Fourth, to Charles Duke of Burgundy, in 1468 : communicated to the ARCHAological Institute of Great Britain and Ireland by Sir Thomas Phillipps, Bart., F.S.A., and, with his permission, by the Central Committee of the Institute to the Society of Antiquaries -

XXII. Description of a Roman Villa discovered at Acton Scott, near Church Stretton, in Shropshire, in 1817 ; with an account of further researches made in July, 1844 : communicated in a Letter from Mrs. Frances Stackhouse Acton to the Very Reverend the Dean of Hereford $\quad 339-345$

XXIII. Letter from M. Octave Delepierre, Secretary of the Belgian Legation, Honorary F.S.A., to Sir Henry Ellis, Secretary, communicating a Document preserved among the Records of West Flanders, relating to the carved Stalls of Melrose Abbey Church - $\quad$ - $\quad$ - 346-349

XXIV. Observations on the Origin and History of the Badge and Mottoes of Edward Prince of Wales. By Sir Nicholas Harris Nicolas, G.C.M.G.: in a Letter addressed to Hudson Gurney, Esq., F.R.S., Vice-President $\quad-\quad 350-384$

XXV. Transcripts of Three Papers from Manuscripts in the British Museum : communicated in a Letter from Sir HEN RY ELLIS, Secretary, to W. R. Hamilton, Esq., V.P. $385-397$

XXVI. On some Anglo-Saxon Remains, discovered at Stowting, in the county of Kent: in a Letter from Chardes Roach Sм1тн, Esq., F.S.A., to Sir Henry Ellis, K.H., F.R.S., Secretary $398-403$

XXVII. An Account of some Specimens of the Works of Maso Finiguerra, the Inventor of the Art of taking Impressions on Paper from Engraved Plates of Metal: by HugH W. Dramond, Esq., F.S.A., in a Letter to Sir Henry Ellis, K.H., F.R.S., Secretary - $\quad$ - $\quad$ - $\quad 404-407$ 


\section{ERRATUM.}

P. 301, 1. 8, for Plate VII. read VIII. 
XXVIII. Description of an Egyptian Mummy, and of the Hieroglyphics upon its Case, supposed to be of the Period of the Psammetici, opened in 1843; in a Letter from HUGH W. DiAMOND, Esq., F.S.A., to John Yonge Akerman, Esq., F.S.A.

XXIX. Letter from John Winter Jones, Esq., of the British Museum, to Sir Henry Ellis, K.H., Secretary, upon the discovery of two rare Tracts in the Library of that Institution, hitherto unknown, from the Press of William Caxton - $\quad$ - $\quad$ - $\quad$ -

XXX. Letter of Sir Harry Stradling to his Wife, written in the year 1456 : communicated by the Rev. JoHn MonTgOMERY Trahenne, M.A., F.R.S.. and F.S.A., in a Letter to the Rev. Joseph Hunter, F.S.A. $425-429$

XXXI. A few Remarks on the Discovery of the Remains of William de Warren, and his wife Gundrad, among the ruins of the Priory of Saint Pancras, at Southover, near Lewes, in Sussex : by Gideon Algernon Manteld, Esq., LL.D., F.R.S., \&c., in a Letter to Sir Henry Ellis, K.H., F.R.S. Secretary $\quad-\quad$ - $\quad$ - $\quad$ - $430-437$

XXXII. Account of T'wo Leaden Chests, containing the Bones, and inscribed with the Names, of William de Warren, and his wife Gundrad, founders of Lewes Priory, in Sussex, discovered in October, 1845, within the Priory precinct: by W. H. BlaAUw, Esq - - - -

XXXIII. A Description of four Bronzes found at Colchester, from the Collection of Henry Vint, Esq. : in a Letter from CHARLES Newton, Esq., to Sir Henry Ellis, K.H., Secretary 443-447

XXXIV. A Letter to George Godwin, Esq., F.R.S., F.S.A., \&c. \&s., on the subject of Remains ascribed to the era of the Druids in Furness, North of Lancashire: by Charles M. JopLiNG, Esq. 
$\mathbf{x}$

Appendix

Presents to the Society Index
CONTENTS.

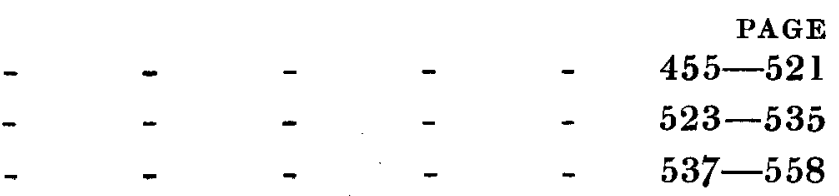

https://doi.org/10.1017/S0261340900012261 Published online by Cambridge University Press 


\section{TABLE OF PLATES.}

I. Dovecote at Garway, in the County of Hereford $\quad$. $\quad$. 191

II. Plan and Section of the Dovecote at Garway $\quad$ • $\quad$ • $\quad$ - $\quad 191$

III. Monumental Effigy of De Mauley in the Minster at York $\quad 248$

IV. Figures of a naked Youth, and of Anacreon and his Dog, from a Fictile Vase in the British Museum $\quad$. $\quad 259$

V. Incised Sepulchral Figures of Knights, at Avenbury in Herefordshire, and Bitton in Gloucestershire . .

VI. Bilingual Inscriptions from two Egyptian Alabaster Vases; one in the Treasury of St. Mark at Venice; the other in the Cabinet du Roi at Paris . . . .

VII. British Remains on Rombald's Moor and Baildon Common, Yorkshire . . . . . . . . . 306

VIII. Plan and Section of British Remains on Rombald's Moor and Baildon Common . • . . . . . 306

IX. Roman Vessels of Glass discovered near Chilgrove in Sussex $\quad 312$

X. Interior of Crypt, looking South. Her Majesty's Palace at Westminster . . . . . . . . . 324

XI. Plan of East end of Crypt, shewing Graves and remains of three Skeletons. Her Majesty's Palace at Westminster 324

XII. Plan of the Roman Villa discovered at Acton Scott $\quad 340$

$\left.\begin{array}{l}\text { XIII. } \\ \text { XIV. }\end{array}\right\}$ Bronze Head of Silenus, found at Colchester A.D. 1845 • 444

XV. Bust of the Emperor Caligula, found at Colchester . $\quad 446$

XVI. Bronze of Jupiter Conservator, found at Colchester A.D. $1844 \quad 447$ 


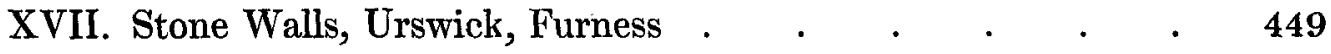

XVIII. Sunbrick, the Kirk, \&c. Furness $\quad$. . . . . . $\quad$ - 450

XIX. The Moat, or Moat Hill, \&c. Furness ․ . . . $\quad 452$

XX. Fig. 1, 2. Viatorium of the time of Queen Elizabeth. Fig.

3. A modern Viatorium purchased at Smyrna . . 482

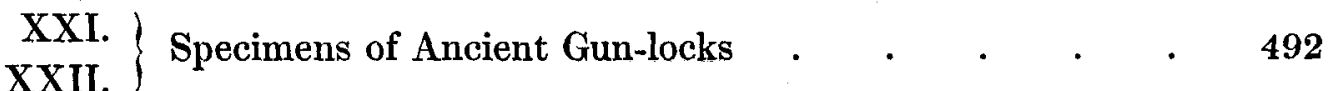

XXIII. British Collar formed of Bronze, found near Embsay, West

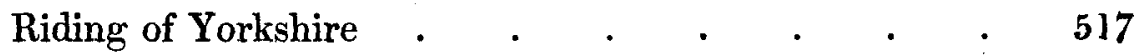

